\title{
The Settler and the Land: Using Patrick Wolfe's logic of elimination to understand frontier violence in Australia's colonial era
}

\author{
Jacob van der Walle \\ University of Technology Sydney, Faculty of Arts and Social Sciences, PO Box 123, Ultimo NSW \\ 2017, Australia. jacob.d.vanderwalle@student.uts.edu.au
}

DOI: https://doi.org/10.5130/nesais.v4i1.1521

\begin{abstract}
Whilst it is the heinous acts of physical violence that are often foregrounded when imagining frontier violence, it is the structural forces of colonialism that have had a continued effect on Aboriginal culture and identity. This essay will discuss the legitimacy of Patrick Wolfe's logic of elimination in the face of frontier violence, examining the more insidious ways in which colonialism manifests itself in modern Australia.
\end{abstract}

Keywords: settler colonialism; frontier violence; Indigenous dispossession

Colonial power both requires and generates the destruction of Indigenous peoples and their societies. For colonialism to succeed, the original inhabitants of the land must be erased and the invasive settler society must supplant the pre-existing polities. Such extinction, however, is not focused on the fanatic destruction of Indigenous culture, but rather the acquisition and expatriation of land, which in turn engenders genocidal acts of dispossession and assimilation. This is Patrick Wolfe's logic of elimination. The concept that settler colonialism always needs more land therefore provides a useful frame for understanding the frontier violence that occurred during Australia's colonial era, illuminating the pervasive colonial foundations that Australian society is built upon. As useful as the logic of elimination may be in deciphering the reasons behind early colonial violence, it is nonetheless important not to trivialise nor provide an operational legitimacy to such violence, and recognise the significant role that racist ideologies and beliefs had during Australia's colonial era. This paper will discuss the legitimacy of the logic of elimination in the face of frontier violence, and offer alternative theories in an attempt to extrapolate meaning from said violence. In doing so, the ongoing impact of colonialism will be examined in order to reveal how the structures it created continue to detrimentally affect Aboriginal Australians.

Recognising that colonialism is concerned with both political conquest and economic exploitation (Morris 1992) assists in understanding the concept behind the logic of elimination and the colonial 
need for more land. It is therefore crucial to understand the social and political context behind the British invasion of Australia. The industrial revolution of the $18^{\text {th }}$ century created a need for land and raw materials. Despite popular depictions of the industrial revolution as a phenomenon restricted to vast industrial metropolises, its effect was profound in urging the British Empire to acquire new land. Land was therefore both a market and a commodity, and such an understanding provides a rationale to the belief that "settler colonialism always needs more land" (Wolfe 2006, p. 395). Central to this pursuit of Western modernity were the sectors of agriculture, forestry, fishing, pastoralism and mining, all of which contributed to the need for expansion and new land, thus providing a context for the colonisation of Australia.

Pastoralism had a significant role in Australia's early colonial pursuits. In New South Wales, wool was particularly vital to the states burgeoning economy and by the 1830s, 1.2 million hectares of New South Wales were alienated for use by European colonists (Morris 1989, p. 10). Such expansion was due to the ever-increasing demand for livestock, and radically transformed the physical landscape (Morris 1989). As the international market demand for wool increased exponentially, colonial pastoralists had great economic motivation for invading and acquiring new land, and their expansion was rapid and often violent (Goodall 1995, p. 65). Wolfe (2006, p. 395) argues that this ceaseless expansion for pastoral land aggressively ate into Indigenous territory, destroying native flora and fauna which limited Indigenous modes of production. This then forced the Indigenous population to become dependent on the foreign colonial economy, and those that hunted livestock, or interfered in the pastoral expansion, became targets for colonial revenge.

When discussing frontier violence, it is pertinent to discuss the often hidden ways in which violence was perpetrated against Aboriginal people. The appropriation of land therefore not only destroyed Indigenous communities and kinship (Tatz 1999), but often became the motivation for acts of physical violence. Unlike other colonial states, there was little exploitation of Aboriginal people by the colonisers during the $18^{\text {th }}$ century. Because the British arrived with their own convict labour force (Goodall 1995), Aboriginal people were not needed to advance the colonial economy (Morris 1989). This differed from the situations in other European colonies, where the original inhabitants were valued due to their 'instrumental worth' in advancing capitalist desires (Morris 1989, p. 14). As a result, the Indigenous populations were regarded as obstacles rather than resources (Morris 1989) and such belief explains the level of violence witnessed during the colonial era. As there was no pressure to engage in peaceful relations with the Aboriginal land owners (Goodall 1995), the expatriation of land was wrought with violence brought on by the desire for expeditious expansion. Such context strengthens Wolfe's logic of elimination and provides an understanding of the minute value the colony placed on Australia's Indigenous population. However, when discussing frontier violence, it is necessary not to frame the violence simply as an auxiliary to the acquisition of land, as doing so subliminally places a sense of legitimacy on the violence that was perpetrated and does not wholly represent the extent of violence committed against Aboriginal people. Indeed, mass killings were often vengeful and not directly involved in expansion (Morris 1992). The Myall Creek massacre is a clear example of such punitive violence, and rather than equating the violence with the need for more land, it uncovers the colonial desire to exterminate the 'other.'

Often cited for the rare prosecution of its white perpetrators, the Myall Creek massacre provides an insight into pervasive colonial thinking. In 1838, 28 Weraerai Aboriginal people were massacred by 
colonial stockmen at Myall Creek in northwestern New South Wales (Wood 2009). Despite the common occurrence of such atrocities, seven of the perpetrators were found guilty and sentenced to death. This genocidal act of extermination was not directly linked with any contest over land, and at first glance seemingly contradicts Wolfe's logic of elimination. However, the reason behind the guilty verdict espoused by Crown prosecutor Roger Therry illuminates colonial thinking on the justification of certain violence. Therry argued that the perpetrators should be punished due to their unjustified and proactive form of violence, and believed the violence exhibited by the perpetrators went beyond the principle of governing force, whereby retaliation was a justifiable source of retribution (Morris 1992, p. 15). Such comments reveal how violence against Aboriginal people was legally justifiable under certain circumstances, namely the acquisition and subsequent protection of colonial land. Clearly, Wolfe's logic of elimination is highly beneficial in understanding colonial attitude towards frontier violence and its quasi-legality.

However, that is not to say that Wolfe's concept stands unopposed and universally accepted. Morris (1992) argues that the violence witnessed during the Myall Creek massacre and other 'bushwhacks' went beyond the need for land and embodies the colonial desire to exterminate the other due to their excess of meaning. By participating in these bushwhacks, colonists attempted to destroy an excess of meaning and restore a singular, Western reality. Such thinking digresses from Wolfe's logic of elimination and suggests that although the desire for land was paramount, there were other factors behind wanton frontier violence. Despite these different theoretical approaches, it is clear that such killings were still within the frame of structural colonial violence; by attempting to remove the other, colonialism attempts to impart its own reality and assert a narrative that effectively erases all signs of indigenous humanity and culture (Wolfe 2006).

As discussed, the mass killings and early frontier violence can be attributed in part to the fact that the existence of a convict labour force meant that Aboriginal people were perceived as surplus with little contribution to economic advancement. However, this shifted during the gold rush of the 1850s. Following the wool market collapse of the 1840s, many white workers left to pursue fantasies of goldinduced wealth, leaving many squatters no option but to employ Aboriginal labour. Goodall (1995, p. 68) asserts that within years, "commissioners for Crown lands were praising Aboriginal stock workers," even believing that certain pastoral industries could now not survive without Aboriginal workers. Coincidentally, mass killings and general violence against Aboriginal people was reduced. Although this demonstrates the viability of Wolfe's logic of elimination in that the violence was subdued once the colonialists understood the value of Aboriginal labour on the land, it begs the question: if Aboriginal people were so adept at Western methods of agriculture, why were they not incorporated into the early colonial economy? The answer lies once again in land and the entitlement of possession. The fear existed that employing Aboriginal labour would create a sense of permanence and integration into the colonial frame (Wolfe 2006). The colonial representations of Aboriginal people were designed to portray the exact opposite: the Aboriginal as a nomad and part of a dying race (Rowley 1970). Allowing Aboriginal people to work on the land and play a role within the colonial economy defied the colonial narrative and reinforces Morris' (1992) belief that much of the early violence was concerned with enforcing the dominant settler narrative. Such thinking introduces ideas of identity and how the early structural violence of colonialism sought to control and represent Aboriginal people for the white man's own benefit. 
The colonial narrative began when the colonisers refused to acknowledge the intricate social and political identities of the Indigenous people of this land. To further entrench the belief that Australia was unclaimed or as it was later legally termed, Terra Nullius, settler colonialism required the representation of Aboriginal people as nomadic and primitive, with no connection to the land and operating individually, without the need for communities (Wolfe 2006). Furthermore, the widespread representations of Aboriginal people as being treacherous, untrustworthy and primitive (Stokes 1997, p. 165) are colonial tools that operate to define the coloniser as natural and grant the settler majority the authority to define Indigenous identity (Lovell 2007). The infiltration of such ideas not only represents Aboriginal people as the other, but also allows the coloniser to assert that they can use the land better than the Indigenous inhabitants; thus, their possession and violence is superficially justified. As distorted as that may be, it established an early narrative that has continued to influence modern governmental policies surrounding Aboriginal issues. As will be discussed, the ramifications of this structural violence are ongoing, and thus the invasion of Australia is better understood as a structure rather than an isolated event (Wolfe 2006).

Both structural and physical violence occurred during Australia's colonial era, and the logic of elimination is useful in deciphering the role of land in such violence. Whilst it is the heinous acts of physical violence that are often brought to the foreground when imagining frontier violence, it is the structural violence of colonialism that has had a continued effect on Aboriginal culture and identity. One of the most powerful structures of colonial violence was the classification and naming of Aboriginal people (Maddison 2013). During the colonial period, Indigenous peoples were subject to racialised categories of identity, based solely off their perceived bloodline (McGregor 2002). Labels were assigned to Aboriginal people who were perceived as 'full blood' or 'half-caste' which dictated their place in colonial society. Wolfe $(2006$, p. 401) asserts that the assimilation policies of the mid $20^{\text {th }}$ century reflected this system of classification and was a structural strategy of elimination, designed to 'bleach Australia white' through programs of reproduction (McGregor 2002, p. 286). The policies of child removal and assimilation were therefore intended to extinguish Indigenous people into invisibility within White Australia (Maddison 2013, p. 289), thus creating a singular reality. Although a subtler form of violence than that witnessed during the colonial era, it was inherently eliminatory in nature, and Wolfe (2006, p. 401) argues that such desire to prevent births within a group is akin to genocide. Clearly, the early colonial narrative regarding the identity of Aboriginal people is reflected in $20^{\text {th }}$ century policy and indicates that although early colonial violence was inextricably linked with the pursuit of land, the structural forms of violence it established have moved beyond such need and remain prevalent today. As a result, Australia has institutionalised settler colonial norms so deeply that even current political ideas and policy administration are informed by them (Lovell 2007).

The structural violence of colonialism continues to impact the lives of Aboriginal people in modern day Australia. Despite the current three-pronged definition of Indigeneity which gives the power of identification to Aboriginal people, Aboriginal people are constantly forced to defend themselves against accusations of inauthenticity (Lamber-Pennington 2012, p. 132). Often Aboriginal people living in Australian cities bear the brunt of these challenges, as the dominant depiction of 'real' Aboriginal people remains the "remote-dwelling, spear-carrying "traditional' Aboriginal person" (Maddison 2013, p. 293). This belief that Aboriginal people living in cities are not authentic as those living in traditional communities is prevalent throughout white society (Shaw 2007), and illuminates 
the fragmentary impact of colonisation on Aboriginal identity as well as the persistence of colonial mentality in modern Australia (Maddison 2013).

The continued structural violence of colonialism is often perpetuated through the media due to its inherent link with political society. Prominent figures such as Andrew Bolt belittle and trivialise Aboriginal struggles of identity, presenting ideas of Indigeneity that echo the racialised ideas of classification from our colonial past. In 2009, Bolt was the respondent in a case involving a breach of the Racial Discrimination Act 1975 (Cth). The subject of the litigation were articles written by Bolt (2009) that extrapolated his idea of 'political Aborigines' as urban Aboriginal people choosing to identify as Aboriginal in order to obtain benefits. His argument centred wholly on the belief that lightskinned people living in urban areas could not possibly be authentic enough to receive such benefits. In doing so, Bolt embodies the colonial belief that it is the white settlers "prerogative to name and contain indigenous identity" (Maddison 2013, p. 298). This example reveals not only an extension of the colonial violence in which settlers attempted to ensure a singular reality as espoused by Morris (1992), but shows how colonial ideas of classification continue to pervade modern thought. Considering the role of the media in shaping legislative public policy and community attitude, it is no stretch to believe that the structural violence established during colonisation continues to affect the lives of Aboriginal people in Australia.

Although the level of physical violence witnessed during Australia's colonial era has ceased, violent forms of political expression continue today. As this paper shows, Wolfe's logic of elimination is helpful in understanding why colonial violence occurred, and presents a concept that can be used to reveal how its violent roots remain embedded in modern Australia. The fact that violence surrounding the acquisition of land has ceased does not in any way discredit Wolfe's claim that colonialism always needs more land. Conversely, it reveals that Australia has become so entrenched in its colonial foundations that the acquisition of land has become peripheral. Rather, the structural violence established by British settlement and its insatiable desire for land continues to maintain control over Indigenous identity and representation, thereby continuing the colonial assault. So, although colonialism has already obtained the land, it is still attempting to control the Aboriginal peoples.

\section{References}

Bolt, A. 2009, 'White is the new black, Herald Sun, 15 April, viewed 12 June 2018, < https://www.heraldsun.com.au/blogs/andrew-bolt/column---white-is-the-new-black/newsstory/2d639a94bb361ca786b9b2c171a4da04>

Goodall, H. 1995, 'New South Wales', in A. McGrath (ed.), Contested Ground: Australian Aborigines Under the British Crown, Allen \& Unwin Academic, Sydney, pp. 55-120.

Lambert-Pennington, K. 2012, 'Real Blackfellas: Constructions and meanings of urban Indigenous identity’, Transforming Anthropology, vol. 20, no. 2, pp. 131-145. https://doi.org/10.1111/j.15487466.2012.01154.x 
Lovell, M. 2007, 'Settler Colonialism, Multiculturalism and the Politics of Postcolonial Identity', Australasian Political Studies Association Conference, Monash University, Melbourne, pp. 1-17.

Maddison, S. 2013, 'Indigenous identity, 'authenticity' and the structural violence of settler colonialism’, Identities, vol. 20, no. 3, pp. 288-303. https://doi.org/10.1080/1070289X.2013.806267

McGregor, R. 2002, 'Breed out the colour or the importance of being white' Australian Historical Studies, vol. 33, no. 120, pp. 286-302. https://doi.org/10.1080/10314610208596220

Morgan, G. 2006, Unsettles places: Aboriginal people and urbanisation in new South Wales, Wakefield Press, Adelaide.

Morris, B. 1989, 'Chapter 1: Colonial Domination as a process of Marginalisation', in Domesticating resistance, 1st edn, Berg, Oxford, pp. 7-30.

Morris, B. 1992, 'Frontier colonialism as a culture of terror', Journal of Australian Studies, vol. 16, no. 35, pp. 72-87. https://doi.org/10.1080/14443059209387119

Rowley, C.D. 1970, The Destruction of Aboriginal Society, ANU Press, Canberra.

Shaw, W. 2007, Cities of whiteness, Blackwell Publishing, Malden, Massachusetts. https://doi.org/10.1002/9780470712931

Stokes, G. 1997, 'Citizenship and Aboriginality: Two conceptions of Identity in Aboriginal Political Thought', in G. Stokes (ed.), The Politics of Identity in Australia, Cambridge University Press, Cambridge, pp. 158-174. https://doi.org/10.1017/CBO9781139166911.012

Tatz, C. 1999, Genocide in Australia, Aboriginal Studies Press, Canberra.

Wolfe, P. 2006, 'Settler colonialism and the elimination of the native', Journal of Genocide Research, vol. 8, pp. 387-409. https://doi.org/10.1080/14623520601056240

Wood, R. 2009, Frontier Violence and the Bush Legend: The Sydney Herald's response to the Myall Creek massacre trials and the creation of colonial identity, History of Australia, vol. 6, no. 3, pp. 67.167.19.

(c) (i) (C) 2018 by the author(s). This article is distributed under the terms and conditions of the Creative Commons Attribution license (http://creativecommons.org/licenses/by-nd/4.0/). 